\title{
Lumen
}

Selected Proceedings from the Canadian Society for Eighteenth-Century Studies

\section{The Yahoo and the Discourse of Racialism in Gulliver's Travels}

\section{Anthony Stewart}

Volume 12, 1993

URI : https://id.erudit.org/iderudit/1012577ar

DOI : https://doi.org/10.7202/1012577ar

Aller au sommaire du numéro

Éditeur(s)

Canadian Society for Eighteenth-Century Studies / Société canadienne d'étude du dix-huitième siècle

ISSN

1209-3696 (imprimé)

1927-8284 (numérique)

Découvrir la revue

Citer cet article

Stewart, A. (1993). The Yahoo and the Discourse of Racialism in Gulliver's

Travels. Lumen, 12, 35-43. https://doi.org/10.7202/1012577ar

Copyright (c) Canadian Society for Eighteenth-Century Studies / Sociéte canadienne d'étude du dix-huitième siècle, 1993
Ce document est protégé par la loi sur le droit d'auteur. L'utilisation des services d'Érudit (y compris la reproduction) est assujettie à sa politique d'utilisation que vous pouvez consulter en ligne.

https://apropos.erudit.org/fr/usagers/politique-dutilisation/ 


\section{The Yahoo and the Discourse of Racialism in Gulliver's Travels}

Swift's description of the Yahoo's physical appearance in Book IV of Gulliver's Travels provides an opportunity for an interrogation of the power of ideology to construct readings through its various apparatuses-among the most influential being the instruments of the academic institution: pedagogy and literary criticism. Such a critique, however, requires that the Yahoo's appearance be seen in the context of the racialist discourse which pervaded eighteenth-century England. Furthermore, since the Yahoo's appearance never changes, such a politicized discussion relieves itself of the burden of the labels 'hard' or 'soft' school-the designations within the fraternity of criticism of Gulliver's Travels which have long served as instruments of valorization for some lines of inquiry and instruments of exclusion for others. ${ }^{1}$ While these 'school' interpretations concentrate on the Yahoo's function in the satire, the Yahoo's physical appearance contributes to the reader's understanding of Swift's description of savagery. I contend that readings of the Yahoo that do not acknowledge the discourse of racialism which stands as its historical context actively conserve the ideology of European cultural superiority across radically different historical moments. Such a critique also suggests a synecdochic relationship between the strategies which suppress the African within the text of Gulliver's Travels and similar strategies of suppression within the writing of history in general.

The term racialism is defined by Kwame Anthony Appiah as the belief

that we could divide human beings into a small number of groups, called 'races,' in such a way that all members of these races shared certain fundamental, biologically heritable, moral and intellectual characteristics with each other that they did not share with members of any other race. (276) 
The crucial element in Appiah's definition is the notion of the 'essence' of a race. Racialism in eighteenth-century England held that the AngloSaxon 'race' was essentially superior to the African 'race.' This belief in an essential superiority rationalized the slave trade since it convinced the English that they were enslaving not human beings but inferior creatures who were neither as capable of suffering nor as sensitive as people of Anglo-Saxon descent.

Sufficient evidence exists that a considerable black presence existed in England at the time of Gulliver's Travels:

In 1555 five Africans were brought into Britain. Over the next century, more and more Africans were imported. By the middle of the seventeenth century at least, a thriving black community had been established, and Britain had ceased to be a white man's country. (Shyllon, Black People 3)

While Shyllon's description of a 'thriving black community' seems to exaggerate the historical circumstances of a people being transported into slavery, his research does point to a notable black presence in England, certainly by the end of the sixteenth century. Francis Adams and Barry Sanders provide further support for the claims of Shyllon and others that England had a considerable black population: 'In 1764, there were nearly 20,000 black men and women in London, and about 30,000 in all of England' (1). Such evidence justifies a reevaluation of such universal terms as 'human nature' in discussions of Swift's satiric target in Book IV, since there was more than one humanity-with more than one cultural heritage and history-living in England when Swift wrote and published Gulliver's Travels. Such evidence also supports the introduction of the work of historians and commentators of varied cultural backgrounds-whose political agendas might differ from those who predominate in conventional English literary criticism -in an attempt to encourage a plurality of readings.

An awareness of the demographics of eighteenth-century England lends a new significance to Swift's descriptions of the Yahoo:

Their Heads and Breasts were covered with a thick Hair, some frizzled and others lank; they had Beards like Goats, and a Long Ridge of Hair down their Backs, and the fore Parts of their Legs and Feet; but the rest of their Bodies were bare, so that I might see their Skins, which were of a brown Buff Colour. (223)

A further description of the Yahoo is even more suggestive: 
a perfect human Figure; the Face of it indeed was flat and broad, the Nose depressed, the Lips large, and the Mouth wide. But these Differences are common to all savage Nations.... (230)

With the exception of the Yahoo's hairiness and its claws, both mere exaggerations of human physical characteristics, these accounts of the Yahoo's appearance evoke typical eighteenth-century descriptions of the African. These descriptions from Gulliver's Travels are consistent with descriptions of the African from such sources as the Encyclopedia Britannica and the writings of Linnaeus, which also concentrate on the shape of the face, proportion of the lips and mouth, and texture of the hair, in addition to skin-colour. ${ }^{2}$ Moreover, within the discourse of eighteenth-century racialism, these physiognomic traits presuppose intellectual and moral characteristics, to restate Appiah's formulation, which identify the African as essentially inferior to the European. Swift's construction of the Yahoo participates in this discourse, thereby conveying economically and efficiently to eighteenth-century European readers an image of the Yahoo's savagery through the already familiar and denigratory constructions of the African.

The homogenizing impulse which conflates all 'savage nations' in a common physiognomy is contradicted by the text of Book IV on at least three occasions. The first such episode occurs soon after Gulliver arrives in Houyhnhnmland, and he pursues a 'beaten Road, hoping it might direct [him] to the Cabbin of some Indian' (224). Secondly, upon his initial arrival at his Houyhnhnm master's house, Gulliver mentions that he has 'some Toys, which Travellers usually carry for Presents to the Savage Indians of America and other Parts' (228). Thirdly, after Gulliver leaves Houyhnhnmland, Swift describes the 'stark naked, Men, Women, and Children' (284) upon whom Gulliver stumbles, and the men of this group who chase him back to his Yahoo-skin canoe.

These three descriptions introduce a notion crucial to a reevaluation of the significance of the Yahoo's physiognomy: that of racial differentiation among non-European peoples. Swift's simple naming of 'Indian' implies his confidence that his eighteenth-century reader will recognize the referent. The undistinguished 'stark naked, Men, Women, and Children' are not identified as 'Indian' and are thereby differentiated as another group of 'savages.' Furthermore, this differentiation makes it clear that Gulliver would have recognized an 'Indian of America' if Swift had presented him with one.

Aphra Behn and Daniel Defoe, both writing before Gulliver's Travels, also differentiate among 'savages.' In Oroonoko Behn points to the uniqueness of the African physiognomy when she describes Oroonoko: 'His nose was rising and Roman, instead of African and flat. His mouth, 
the finest shap'd that cou'd be seen; far from those great turned lips, which are so natural to the rest of the Negroes' (10). Significantly, Behn attempts to imbue Oroonoko with an uncommon nobility by describing his face as more closely resembling a European face. In Robinson Crusoe, Crusoe describes Friday: 'His Face was round, and plump; his Nose small, not flat like the Negroes, a very good Mouth, thin lips ... '(160). Both Behn's and Defoe's descriptions exhibit an ability and a willingness in the eighteenth century to distinguish among non-Europeans.

This capacity for racial differentiation shows how the time-worn assertion that the Yahoo is an abstract, benign conglomerate of the physical characteristics of all 'savages' appears to misread the textual evidence. The argument that the Yahoo is an apolitical assemblage of non-European physical traits occludes the over-arching racialism to which Swift's construction of the Yahoo contributes and by which it is informed. Within this discourse the representation of a savage must be someone who is Other, not European, and Swift models his savage after the people most often equated in eighteenth-century England with sub-human savagery.

Once the Yahoo's physical appearance is historicized Swift's description of the Yahoo's history also supports the reading-in of the African into Gulliver's Travels. Perhaps the most compelling detail from the Yahoo's history concerns the Houyhnhnms' problem regarding the Yahoo population. At the Houyhnhnm council Gulliver's master suggests that, instead of exterminating the Yahoos, the younger Yahoos be castrated, 'rendering them tractable and fitter for Use ...' (273), also eventually ridding Houyhnhnmland of this nuisance by stopping them from reproducing. He also recommends the cultivation of asses, since they may be put to work at the age of five years while the Yahoo cannot be put to work until twelve years (273). The same method of population control-absolute control over reproduction-was used by the planters who ran the West Indian sugar plantations of the eighteenth century. The planters 'had no interest in making the slave population selfreproducing ... [since] ... a slave child was a liability for at least twelve years before it could be put to work...' (Adams and Sanders 3). The coincidence of the working ages of the two societies' slaves again suggests Swift's participation in a discourse which fated the African's entire life as one of servitude at the feet of the European. ${ }^{3}$

The African's contribution to the construction of the Yahoo is crucial yet silently relegated to the background, reduced, as Chinua Achebe writes in relation to Heart of Darkness, to a 'setting and backdrop which eliminates the African as human factor' (9). The dehumanization and neutralization of the African is perpetuated whenever Book IV is read 
by post-eighteenth-century critics without the acknowledgement of the historical conditions which helped to produce it. The suppression of the African in discussions of Book IV perpetuates the strategy of cultural domination which Edward Said calls Orientalism, which 'isand does not simply represent-a considerable dimension of modern political-intellectual culture, and as such has less to do with the Orient than it does with 'our' world' (Orientalism 12). 'Our' world is the world and culture of Europe. Any Other which exists outside this world is subject to domination and identification based upon criteria established by Europeans. In Said's words, 'Orientalism ha[s] the epistemological and ontological power virtually of life and death, or presence and absence, over everything and everybody designated as 'Oriental" (World, Text, Critic 223). While Orientalism presupposes a fascination with things 'Oriental,' an analogous Africanism involves a similar distinction between the European and the African, and an attendant disdain directed from the former towards the latter. In the case of Africanism, the effect has been to suppress the African's presence, since an acknowledgement of the African in English history cannot but acknowledge England's lengthy and lucrative involvement in the African slave trade. A recognition of the Yahoo's cultural origin leads to a critique of the values which inform the literary critical practices that have historically produced and continue to produce Gulliver's Travels.

The suppression of the African in Book IV serves the interest of the dominant ideology, the framework of assumptions which create a sense of what is 'obvious' and 'natural' to the world we live in. This suppression, then, is crucial in directing attention away from the Yahoo's historical referent, since, as James Kavanagh sums up this point, 'the power to define what is 'obvious' helps to determine who rules' (318). In the case of Gulliver's Travels, for instance, the ideology which evaluates this text as one the best of this culture's achievements is conserved by Africanist critical practices which ignore the fact of England's more than two-hundred-year involvement in the slave trade. These same practices perpetuate the 'myth of Anglo-Saxon humanity and benevolence' (Adams and Sanders 15). The conservation of this myth is essential to the maintenance of the status of texts like Gulliver's Travels. Africanism tacitly demotes issues of the African slave trade to the ranks of the extra-literary, thereby dictating that these issues should not impinge upon a reading of Book IV. Once these notions of what is obvious are challenged, the workings of ideology become the object of critique and new, interrogatory methods of reading are free to emerge. With these emerging methods of reading come new understandings of traditional power relationships. 
The workings of ideology are put into relief within the institution of Gulliver's Travels criticism by the contention that the Yahoos represent the Irish, a claim which has been made by several commentators. Concerning the anti-colonialist salvo Swift launches near the end of Book IV, Claude Rawson writes: 'when Swift is denouncing colonial conquest no reference to flat noses, large lips or likeness to monkeys is allowed to enter into the mention of subject races' (170). Rawson feels that this passage stood a better chance of arousing 'anger against the oppressor' (170) in an eighteenth-century European audience if it omitted such specific racial information. His point is that the oppressed people of this passage are the Irish, whom, he says, Swift 'despised as a species of sub-human animal and for whom he nevertheless felt a kind of fierce compassion' (170). By emphasizing the Irish as the objects of colonialist barbarities Rawson reproduces what was probably Swift's attitude to colonialism. Eighteenth-century Europeans were more likely to be outraged by colonialist horrors committed against other Europeans rather than against Africans.

Irvin Ehrenpreis helps clarify this point, quoting Swift's definition of slavery as "[g]overnment without the consent of the governed" (132). He also states that in 1710 Swift 'accused England of trying to enslave his compatriots, and he never discarded that conviction' (137). In a discourse where the African was not seen as human, then, a man so concerned with the liberty of one group of people - the Irish-need not have been concerned with the liberty of all subjected peoples. Moreover, it is not contradictory, within the workings of this discourse, to further dehumanize one group in order to appeal for the humanity of another. Therefore, it is possible that the Yahoos were to be perceived consciously by Swift's European readers as the Irish, especially at the end of Book IV, when Swift provides a sweeping condemnation of colonialism. However, the acknowledgement of this possibility only makes my critique of Africanism stronger. The fact that the Irish have been written into the text, by Rawson, Anne Cline Kelly, and others, reinforces the exclusion of the African from the same text. The only thing more de-humanizing than being insulted in a text, is to be insulted while being excluded from that text which insults you. The African's suppression from Book IV effects such insult.

In the case of Gulliver's Travels, criticism conserves the dominant ideology by naturalizing values of eighteenth-century England into transhistorical, universal values, ignoring the political implications of such a project and, in fact, making it appear 'obvious' that these processes are free of political interest. However, slavery contributed to the economic base for England's first phase of imperialist expansion and produced huge amounts of wealth for untold numbers of men. Accord- 
ing to David Dabydeen, Swift himself invested 'hundreds of pounds, in 1720 , in the South Sea Company whose sole business at the time was to ferry African slaves to the Spanish colonies' (44). While most twentiethcentury standards of morality would identify such involvement as unconscionable, most eighteenth-century morality did not. Slavery was deemed necessary to the economic well-being of England. This emphasis on economics justified England's involvement in slavery by replacing issues of morality with issues of economic expediency.

Judging an eighteenth-century practice immoral based on twentiethcentury standards of morality dislocates the practice under examination from its own historical moment, forcibly and fallaciously locating it unreconstructed in another. While it is not surprising that Swift chooses for his depiction of savagery the model of the African as constructed by eighteenth-century racialist discourse, it is surprising that twentiethcentury critics-more specifically, critics of the last twenty years, when critical methods have largely discredited universalist notions of reading-repeatedly reinscribe this eighteenth-century discourse, reproducing it in criticism which should be aware of the racialist exploitation characteristic of this historical moment. Africanism contributes to what Laura Brown calls 'the general neglect of race and slavery among critics of eighteenth-century literature' ('Romance of Empire' 42). Such criticism reproduces Swift's eighteenth-century methodology by suppressing the African in silence.

In two recent articles, Laura Brown ('Reading Race and Gender') and Clement Hawes have also addressed colonialist constructions in Gulliver's Travels, although with different emphases. While our approaches share some historical evidence in common, there remains a need for a stated priority which will emphasize the existence and effects of racialist constructions in texts canonized as 'classics.' This has been my priority here. Such a project will encourage a critique of the institutional praxes of Africanism which, in their various forms, naturalize and maintain Eurocentric ideology.

ANTHONY STEWART

Queen's University 


\section{Notes}

1 Sullivan succinctly describes the 'hard' and 'soft' schools of criticism and provides a sample of each school's determinations of the Yahoos' and the Houyhnhnms' roles in Book IV, including such 'softer than soft' (498) 'school' readings as Kelly's. Rodino also discusses the 'hard' and 'soft' school controversy, finally citing James Clifford's conclusion that 'current hard and soft theories now accept them [the Yahoos] as the limits to which men might degenerate' (xxxi).

Such a determination equivocates on the notion of a common humanity, a notion which must be examined critically before blithely describing Book IV as a satire of all humanity. My point is that the lesson concerning 'the limits to which men might degenerate' is directed only towards eighteenth-century European readers, who would recognize in the African the savagery Swift ascribes to the Yahoo.

2 Popkin provides a digest of some of the prevailing eighteenth-century theories and statements regarding the appearance and behaviour of Africans. Invariably, physical observations were accompanied by extrapolations on moral and/or sexual characteristics. Popkin lists such luminaries as Locke, Berkeley, Hume, Voltaire, Franklin, Jefferson, and Kant as having 'expressed views that sound shockingly racist today' (245).

3 Swift also describes the Yahoos, who are, of course, owned by the Houyhnhnms, as 'tied by the Neck with strong Wyths, fastened to a Beam' (229), an image reminiscent of the African's enslavement in England and in the colonies, where 'collars and padlocks were deemed a necessary part of the livery of black chattels' (Shyllon, Black Slaves 9). Gulliver's Travels also features speculation into the origins of the first Yahoos in Houyhnhnmland: the Yahoo 'had not always been in their [the Houyhnhnms'] Country' (271) and one Houyhnhnm theory posits that 'the two Yahoos said to be the first seen among them, had been driven thither over the Sea; ... [and] became in Process of Time, much more savage than those of their own Species in the Country from whence these two Originals came' (272). The Yahoo's arrival in Houyhnhnmland by sea suggests the English slave ships which began transporting African slaves to England in 1555 and were by 1713 , thanks to the lucrative Asiento clause in the Treaty of Utrecht, supplying British and Spanish colonies with African slaves. Adams and Sanders state that ' [w]ell over two million Africans were transported to the New World in English ships between 1680 and 1786' (1); Brown states that 'at least six million human beings were forcibly transported across an ocean, to produce a massive new work force on two continents and in the islands of the West Indies' ('Romance of Empire' 42-43).

\section{Works Cited}

Achebe, Chinua. 'An Image of Africa.' Research in African Literatures 9 (1978): 1-15.

Adams, Francis D., and Barry Sanders. 'Introduction: Historical Setting.' Three Black Writers in Eighteenth Century England. Belmont, CA: Wadsworth, 1971. 1-16.

Appiah, Kwame Anthony. 'Race.' Lentricchia and McLaughlin 274-87. 
Behn, Aphra. Oroonoko; or, The Royal Slave: A Critical Edition. Ed. Adelaide P. Amore. Lanham: UP of America, 1987.

Brown, Laura. 'Reading Race and Gender: Jonathan Swift.' The Politics of Difference. Spec. issue of Eighteenth-Century Studies 23.4 (1990): 424-43.

-. 'The Romance of Empire: Oroonoko and the Slave Trade.' The New Eighteenth Century: Theory / Politics / English Literature. Ed. Felicity Nussbaum and Laura Brown. New York: Methuen, 1987. 41-61.

Dabydeen, David. 'Eighteenth-Century English Literature on Commerce and Slavery.' The Black Presence in English Literature. Ed. Dabydeen. Manchester: Manchester UP, 1985. 26-49.

Defoe, Daniel. Robinson Crusoe. Ed. Michael Shinagel. New York: Norton, 1975.

Ehrenpreis, Irvin. 'Swift on Liberty.' Journal of the History of Ideas 13 (1952): 131-46.

Hawes, Clement. 'Three Times Round the Globe: Gulliver and Colonial Discourse.' Cultural Critique 18 (1991): 187-214.

Kavanagh, James H. 'Ideology.' Lentricchia and McLaughlin 306-20.

Kelly, Anne Cline. 'Swift's Explorations of Slavery in Houyhnhnmland and Ireland.' PMLA 91 (1976): 846-55.

Lentricchia, Frank, and Thomas McLaughlin, eds. Critical Terms for Literary Study. Chicago: U of Chicago P, 1990.

Popkin, Richard H. 'The Philosophical Basis of Eighteenth-Century Racism.' Racism in the Eighteenth Century. Ed. Harold E. Pagliaro. Studies in Eighteenth-Century Culture 3 (1973): 245-62.

Rawson, Claude. 'Gulliver, Marlow and the Flat-Nosed People: Colonial Oppression and Race in Satire and Fiction.' Dutch Quarterly Review of Anglo-American Letters 13 (1983): 162-78, 282-99.

Rodino, Richard H. Swift Studies, 1965-1980: An Annotated Bibliography. New York: Garland, 1984.

Said, Edward W. Orientalism. New York: Pantheon, 1978.

- The World, the Text, and the Critic. Cambridge, MA: Harvard UP, 1983.

Shyllon, Folarin. Black People in Britain 1555-1833. London: Oxford UP, 1977.

—. Black Slaves in Britain. London: Oxford UP, 1974.

Sullivan, E.E. 'Houyhnhnms and Yahoos: From Technique to Meaning.' Studies in English Literature, 1500-1900 24 (1984): 497-511.

Swift, Jonathan. Gulliver's Travels. Ed. Herbert Davis. Oxford: Blackwell, 1965.

Wilding, Michael. 'The Politics of Gulliver's Travels.' Studies in the Eighteenth Century. Ed. R. F. Brissenden. Toronto: U of Toronto P, 1973. 303-22. 